\title{
Management Practices and Perceived Training Needs of Livestock Farmers in Arid region of Rajasthan
}

\author{
Ram Niwas*, Charu Sharma, Sunil Kumar Sharma and Chandra Prakash Meena \\ Krishi Vigyan Kendra, Pokaran-345021 Jaisalmer(Rajasthan) India \\ (Swami Keshwanand Rajasthan Agricultural University, Bikaner) \\ *Corresponding author
}

\begin{abstract}
A B S T R A C T
Present study was conducted to assess management practices and perceived training needs of livestock farmers in arid region of Rajasthan state India. Interview schedule was used to collect data from one hundred forty randomly selected farmers. Ninety five percent of the respondents kept cow only, $40.71 \%$ kept sheep only, $86.42 \%$ kept goat only while 57\%

kept cow, goat and sheep combined. Majority (93.57\%) of the respondents kept their animals under the loose housing system of management, 9.28\% kept intensive housing and $25 \%$ kept both housing systems. Very few (1.42\%) of the farmers interviewed kept farm records. All the respondents had basic knowledge on how a healthy animal should look like. About seventy percent indicated that Ephermal fever, Botulism, repeat breeding, Black quarter and FMD in cattle; Enterotoxaemia, PPR, Sheep pox, diarrhoea in goat and sheep was the most frequently observed health problem in their flocks. A high percentage of the respondents indicated training needs in the area of clean milk production (93.57\%), improvement in animal productivity $(87.14 \%)$, prevention of animal diseases and health management practices $(84.28 \%)$, protection measures during extreme climatic situation (79.28\%), genetic improvement and indigenous breed conservation $(75.71 \%)$, risk reduction through animal insurance $(67.85 \%)$, livestock Waste management $(65 \%)$, ration formulation $(63.57 .0 \%)$, artificial insemination $(62.14 \%)$, Improvement in Nutritious value of available fodder $(52.85 \%)$ and commercial livestock farming $(42.14 \%)$. Great potentials exist for livestock production in the arid region and this can be achieved through sound extension education and need based training programme to the farmers.
\end{abstract}

Keywords

Livestock; Need,

Training; Health;

Indigenous breed and Production

Article Info

Accepted:

20 June 2021

Available Online:

10 July 2021

\section{Introduction}

Livestock plays an important role in the rural economy of India in general and sustainable livelihood of poor people of rain-fed agroecosystem in particular, because of inherent risk involved in the crop farming due to uncertainty of rainfall and occurrence of recurrent droughts (Misra, 2005). In India, income from livestock production accounts for 15-40\% of total farm household earnings (World Bank, 1999). Apart from the monetary benefits provided by milch animals, the role of small ruminants like goats and sheep is very important, as they serve as a lifeline during drought years by providing income and sustenance (Anupama et al., 2018). Although the productivity of livestock in arid 
zone is low (Devi Singh and Hema Tripathi, 2016), there is ample opportunity for improvement. Such improvement can be achieved through extension and training of livestock producers. However, such extension education and training can only be effective if the training needs of the livestock producers are properly identified. There is poor awareness regarding ways of improving livestock productivity to improve livelihoods. The measure suggested for removing the obstacle is to train rural livestock farmer to improve their ability to do their vocation more effectively and efficiently. Meanwhile, a prerequisite to reach this, is to access information needs and information seeking behavior of the farmer. Improving the knowledge and skills of faremer about how improving the productivity of livestock would bring in a short time quantitative and qualitative improvements in the livestock production. Numerous studies confirm the positive effects of agricultural education and extension in farm productivity (Alene and Manyong, 2007), poverty alleviation (Dercon et al., 2009), capacity building (Krishna et al., 2013), acquisition of general knowledge about new methods and principles in agriculture and animal husbandry (Karbasioun et al., 2008). Need assessment helps to identify the present problems and future challenges to meet through training and development. In order to make any training meaningful and effective, it is imperative on the part of the training organizers to identify the training need of the farmers based on which a suitable training module can be developed so that the appropriate training is given to the right people, in the right form, at the right time so that the degree of productivity and profitability can be achieved Dhaka et al., (2017). Chai et al., (2013) described need analysis as an examination of the existing need for training within an organization. Livestock plays an important role in arid region i.e. Nagaur, Pali, Jodhpur,
Jaisalmer and Badmer district of Rajsthan for employment and livelihood of rural people. Capacity building at an individual level needs the formation of an environment that allows individual participants to build and enhance existing knowledge and skills. For this, analysis of existing knowledge, practices, and training need is a pre requisite, based on which there should be enough opportunities for continued learning. The study throws light on the prevailing conditions in the field of livestock farming. This study was therefore conducted to describe, existing management practices, factors discouraging farmers' participation in training and ascertain livestock farmers' training needs in arid region adjoining Pokaran areas of district Jaisalmer (Rajasthan) India.

\section{Materials and Methods}

The present study was carried out by Krishi Vigyan Kendra, Pokaran (Jaisalmer) Rajasthan during the year 2018-19 in seven villages i.e. Gomat, Dudhiya, Biliya, Morani, Didaniya, Badli Manda and Badli Nathusar adjoining area of Pokaran region of Jaisalmer district of Rajasthan. Only 140 livestock farmers were randomly selected from those seven villages. Twenty livestock farmers were randomly selected from each of these seven villages; thus a total of one hundred forty farmers constituted the sample size for the study. Semi-structured interview schedule was used to collect data for the study. Information on the existing livestock management practices (feeds and feeding, housing, health and disease preventive measures, breeding and record keeping) health problems and existing knowledge level were sought from the respondents as well as government veterinary officers. Information on the perceived training needs of the livestock farmers was also elicited. The gathered data were processed, tabulated, classified and analyzed in terms of percentage 
in the light of objectives of the study. Factors that could discourage their participation in the training programmes were obtained on a fourpoint Likert-type scale of strongly agree (4), agree (3), disagree (2) and strongly disagree (1). A mean score (2.5) was determined by adding 4, 3, 2 and 1 and dividing the sum by 4. Any factor with a mean score of 2.5 and above was taken as a discouraging factor. Data generated in the study were presented as percentage and mean scores.

\section{Results and Discussion}

\section{Existing animal husbandry practices}

Ninety five percent of the respondents kept cow only, $40.71 \%$ kept sheep only, $86.42 \%$ kept goat only while $57 \%$ kept cow, goat and sheep combined (Table 1). Indigenous cow, Marwari goat and sheep kept by the respondents in the study area having high degree of adaptability (Ebegbulem et al., 2011). Majority (93.57\%) of the respondents kept their animals under the loose housing system of management, 9.28\% kept intensive housing and $25 \%$ kept both housing system. Most of the respondent followed loose housing system due to availability of large area and low investment. The forages used for feeding the animals were indicated by $5.71 \%$ of the respondents to be available all year round. It may be due to unavailability of water and low rainfall. Cyamopsis tetragonoloba, Pennisetum typhoid, Vigna radiate, Prosopis cineraria, Ziziphus mauritiana, Arachis hypogaea, Triticum Speciesis combination were the most commonly used forage fed to the animals. Further knowledge on health of livestock kept $44.28 \%$ by the respondents that indicated they have basic knowledge on how a healthy animal should look like. Signs of ill health that could be recognized by the farmers were diarrhea, dull appearance, weakness, weight loss, excessive bleating and lack of appetite.
Similarly $27.14 \%$ of the respondents were used reduced disease measures like use of cleaner pastures, reducing stocking rate through sale of mature and less productive animals and separating sick from healthy animal. Thirty percent of the farmers selected animals for breeding on the basis of fast weight gain and high rate of multiple births. Other factors that are taken into consideration when selecting breeding animals included productivity, ability to thrive on forage alone, mothering ability and resistance to internal parasites. Very few (1.42\%) of the farmers interviewed kept farm records. This indicates that farmers in the study area were not aware of the innumerable importance of record keeping. Present finding collaborates with result of Chah et.al. (2013) and Pourouchottamane et al., (2012). Further Yami (2009) noted that record keeping is an important and necessary aspect of operating even the smallest farming enterprise; where by farm records can assist the farmer in making farm management and business decisions.

\section{Observed health problem/ diseases}

Majority $(80 \%)$ of the farmers indicated that botulism was the most frequently observed health diseases while repeat breeding found $68.57 \%$ in their cow (Table 2). Respondent observed FMD (79.28\%) and Black Quarter (60 \%) in the animals. Further Enterotoxaemia in Sheep and PPR in goat reported by $50.71 \%$ and $48.57 \%$ respectively. Thirty percent of the respondents reported "sheep pox" as a frequently encountered health problem. Farmers observed diarrhea (40.71\%) amongst animals whereas majority $(87.85 \%)$ of the respondent found tics and mites problems in their animals. Similar result was reported by Devi Singh and Hema Tripathi (2016). Helminthosis and PPR have being identified as major disease problem of small ruminants. 
Tabel.1 Percentage Distribution of respondents according to type of existing animal's husbandry practices $(\mathrm{N}=140)$

\begin{tabular}{|l|l|l|}
\hline \multicolumn{1}{|c|}{ Attributes } & Frequency & \multicolumn{1}{c|}{ Percentage } \\
\hline Cow only & 133 & 95.00 \\
\hline Goat only & 121 & 86.42 \\
\hline Sheep only & 57 & 40.71 \\
\hline Combine all & 86 & 61.42 \\
\hline Loose Housing System & 131 & 93.57 \\
\hline Intensive housing system & 13 & 9.28 \\
\hline Both loose and intensive system & 35 & 25 \\
\hline Availability of forages all year-round & 8 & 5.71 \\
\hline knowledge on health of livestock & 62 & 44.28 \\
\hline Measures used to reduce disease incidence & 38 & 27.14 \\
\hline Selection of breeding animals. & 42 & 30.00 \\
\hline Keep animal records & 2 & 1.42 \\
\hline
\end{tabular}

Table.2 Percentage distribution of respondents according to frequently observed livestock health problem $(\mathrm{N}=140)$

\begin{tabular}{|l|l|l|}
\hline Health problem/diseases & Frequency & percentage \\
\hline Botulism in cow & 112 & 80.00 \\
\hline Repeat breeding in cow & 96 & 68.57 \\
\hline FMD & 111 & 79.28 \\
\hline Black quarter & 84 & 60.00 \\
\hline Enterotoxaemia in Sheep & 71 & 50.71 \\
\hline PPR in Goat & 68 & 48.57 \\
\hline diarrhea & 57 & 40.71 \\
\hline Sheep Pox & 42 & 30.00 \\
\hline Tics and mites & 123 & 87.85 \\
\hline
\end{tabular}

Table.3 Percentage distribution of respondents according to awareness about animal husbandry practices $(\mathrm{N}=140)$

\begin{tabular}{|l|l|l|}
\hline Awareness about & Frequency & Percentage \\
\hline Breed specific character & 38 & 27.14 \\
\hline Age of sexual maturity in animals & 59 & 42.14 \\
\hline Heat detection and Signs of calving & 68 & 48.57 \\
\hline Feeding methods & 45 & 32.14 \\
\hline Castration and Gestation period & 61 & 43.57 \\
\hline Clean milk production & 11 & 7.85 \\
\hline Causes of pregnancy loss and care during pregnancy & 14 & 10.00 \\
\hline Housing system & 48 & 34.28 \\
\hline Complication during calving and Care after birth & 36 & 25.71 \\
\hline Lactation period in animal & 79 & 56.42 \\
\hline Calving interval and best breeding season & 51 & 36.42 \\
\hline diseases control measures & 53 & 37.85 \\
\hline
\end{tabular}


Table.4 Percentage distribution of respondents on the basis of technical training need $(\mathrm{N}=140)$

\begin{tabular}{|l|l|l|}
\hline \multicolumn{1}{|c|}{$\begin{array}{c}\text { Training needs } \\
\text { (Willingness to be trained) }\end{array}$} & Frequency & Percentage \\
\hline Protection measures during extreme climatic situation & $\mathbf{1 1 1}$ & $\mathbf{7 9 . 2 8}$ \\
\hline Improvement in animal productivity & $\mathbf{1 2 2}$ & $\mathbf{8 7 . 1 4}$ \\
\hline $\begin{array}{l}\text { Prevention of animal diseases and Health management } \\
\text { practices }\end{array}$ & $\mathbf{1 1 8}$ & $\mathbf{8 4 . 2 8}$ \\
\hline Clean milk production & $\mathbf{1 3 1}$ & $\mathbf{9 3 . 5 7}$ \\
\hline Scientific Feeding of animals & $\mathbf{8 5}$ & $\mathbf{6 0 . 7 1}$ \\
\hline Genetic improvement and indigenous breed conservation & $\mathbf{1 0 6}$ & $\mathbf{7 5 . 7 1}$ \\
\hline Ration's formation & $\mathbf{8 9}$ & $\mathbf{6 3 . 5 7}$ \\
\hline Livestock Waste management & $\mathbf{9 1}$ & $\mathbf{6 5 . 0 0}$ \\
\hline Artificial insemination & $\mathbf{8 7}$ & $\mathbf{6 2 . 1 4}$ \\
\hline Risk reduction through animal insurance & $\mathbf{9 5}$ & $\mathbf{6 7 . 8 5}$ \\
\hline Improvement in Nutritious value of available fodder & $\mathbf{7 4}$ & $\mathbf{5 2 . 8 5}$ \\
\hline Commercial livestock farming & $\mathbf{5 9}$ & $\mathbf{4 2 . 1 4}$ \\
\hline
\end{tabular}

These health challenges result in severe economic losses due to death of affected animals or reduced productivity and live weight gain.

\section{Awareness level about animal husbandry practice}

Data in table 3 show that majority of livestock farmers had knowledge level in Clean milk production (7.85 \%), Causes of pregnancy loss and care during pregnancy (10\%), Complication during calving and Care after birth (25\%), Breed specific character (27.14), Feeding methods (32.14\%), Housing system (34.28\%), Calving interval and best breeding season $(36.42 \%)$, diseases control measures (37.85\%), Age of sexual maturity in animals (42.14\%), Castration and Gestation period (43.57\%), Heat detection and Signs of calving (48.57\%) and Lactation period in animal (56.42 \%) respectively. Knowledge level about animal husbandry practices are an essential component for high productivity. Present result in agreement with the finding of Dhaka et al., (2017). However, it has always been recognized that to achieve good results and make the best of the selected characteristics, the animals must be provided with good nutrition, health care and husbandry techniques (Roberts, 2000). Similar results were also reported by Farinde and Ajayi (2005). Thus, it was suggested that extension services to farmer women needs to be improved so that they can access the relevant information on the good management practice of sustainable livestock production.

\section{Perceived training needs}

Although farmers need training in all the variables listed on Table 4, a high percentage of the respondents indicated training needs in the area of clean milk production $(93.57 \%)$, Improvement in animal productivity $(87.14 \%)$, Prevention of animal diseases and Health management practices (84.28\%), Protection measures during extreme climatic situation (79.28\%), Genetic improvement and indigenous breed conservation (75.71\%), Risk reduction through animal insurance (67.85\%), Livestock Waste management(65 $\%)$, ration formulation $(63.57 .0 \%)$, Artificial 
insemination (62.14\%), Improvement in Nutritious value of available fodder $(52.85 \%)$ and Commercial livestock farming (42.14\%). Extension in the study area should therefore make efforts to organize training programmes that will cover these areas of needs of the farmers. Institutions should take into consideration of the training needs of livestock farmers so that they may acquire the relevant Knowledge and skill in the new techniques and the same may be imparted to the farmers and they can also upgrade the existing knowledge in better manner. Present study is agreement in the result of Raghavendra et al., (2018). Rezvanfar et al., (2007) was also reported similar results. Farinde and Ajayi (2005) reported that in order to sustain the interest and motivation of the rural population towards their economic empowerment, their felt needs should be addressed. Failure of agricultural extension training programmes to capture farmers' perceived training needs will result in huge loss of resources.

\section{Perceive factors discouraging farmers' participation in training programmes}

Five perceived factors that could discourage farmers' participation in training programmes (Table 5) were identified viz: The content of training programs does not meet perceived needs $(\mathrm{M}=2.7)$, lack of free time to devote to training activities $(\mathrm{M}=2.8)$, training programmes are targeted to well highly educated farmers $(M=2.7)$, not all farmers have free access to training programmes $(\mathrm{M}=2.9)$, lack of training programmes for livestock farmers $(\mathrm{M}=2.6)$ and participation in a training programme will not really benefit me $(\mathrm{M}=2.6)$.To improve livestock farmers' participation in livestock training programmes in the study area, information on these programmes should be disseminated via the various forms of mass media particularly religious organizations and social groups.
The training programmes should be designed in such a way that even the uneducated farmers will be actively involved in the training. Thus, training sessions can be conducted in both Hindi and local languages.

In conclusion the great potentials exist for livestock production in arid region of Rajasthan state India. Farmers need sound extension education and training skill to achieve these potentials. It is highly recommended to giving adequate training and awareness to the livestock farmer in the various aspects of good management practices for sustainable livestock production. However, for these potentials to be achieved, the training needs and factors discouraging participation identified in this study should be taken into consideration in developing any livestock training programme in the area. Capacity building at an individual level needs the formation of an environment that allows individual participants to build and enhance existing knowledge and skills. In order to make any training meaningful and effective, it is imperative on the part of the training organizers to identify the training need of the farmers based on which a suitable training module can be developed.

\section{References}

Alene, A.D. and Manyong, V. M. 2007. The effects of education on agricultural productivity and improved technology in Northern Nigeria: An endogenous switching regression analysis. Emp. Econs., 32:41-159.

Anupama Jena, Prasanta Kumar, Mishra, K. and Sadhna Ojha. 2018. Training needs of goat farmers: An analysis. The Pharma Innovation Jour., 7(7): 844-847.

Chah, J. M., Obi, U. P. and Ndofor-Foleng, H. M. 2013. Management practices and perceived training needs of small ruminant farmers in Anambra State, Nigeria. African Journal of Agricultural Research, 8(22):2713-2721. 
De Winter, J. C. F. and Dodou, D. 2010. "FivePoint Likert Items: t test versus MannWhitney-Wilcoxon." Practical Assessment, Research \& Evaluation., 15: 11.

Dercon, S., Gilligan, D. O., Hoddinott, J. and Woldehanna, T. 2009. The impact of agricultural extension and roads on poverty and consumption growth in fifteen Ethiopian villages. Am. J. Agric. Econ., 91:1007-1021.

Devi Singh and Hema Tripathi 2016. Incidence of diseases among livestock in arid zone of rajasthan. The Indian Journal of Field Veterinarians, 6:11-14.

Dhaka, B. L., Bairwa, R. K., Meena, N. L., Meena, G. S., Chayal, K. and Nagar, B. L. 2017. Training Needs Assessment of Women Farmers on Livestock Production Management in Bundi District of Rajasthan, India. Int.J.Curr.Microbiol.App.Sci., 6(6): 796803.

Ebegbulem, V. N., Ibe, S. N., Ozung, P. O. and Ubua, J. A. 2011. Morphometric trait characteristics of west African dwarf goats in Abia State South East Nigeria. Contin. J. Agric. Sci., 5:1-6.

Farinde, A. J. and Ajayi, O. A. 2005. Training needs of women farmers in livestock production: Implications for rural development in Oyo State of Nigeria. J. Soc. Sci., 10:159-164.

Raghavendra, K., Chowdary, G., Prasad Babu and Jayalakshmi Mitnala 2018. A Study on Training Need Assessment among farmers in Kurnool District of Andhra Pradesh. Bulletin of Environment,
Pharmacology and Life Sciences, 7 (8): 47-51

Karbasioun, M., Biemans, H. and Mulder, M. 2008. Farmers' learning strategies in the province of Esfahan. J. Agric. Edu. Ext., 14:307-318.

Krishna priya, N. and Sivanarayana, G. 2013. Review on Training Need Analysis of Agricultural Officers and Agricultural Extension Officers. Global Journal for Research Analysis, 2(9): 1-3.

Misra, A. K. 2005. Contingency planning for feeding and management of livestock during drought. In: K D Sharma and K S Ramasastri (Eds) Drought Management. Allied Publishers Pvt. Ltd., New Delhi. Pp. 276-286.

Pourouchottamane, R., Venkatasubramanian, V., Singha, A. K., Mishra, A. and Pankaj, P. K. 2012. Training needs analysis of livestock farmers and rural youths of north eastern india.Veterinary Practitioner, 13(2):374-379.

Rezvanfar, A., Moradnezhai, H. and Vahedi, M. 2007. Information needs of farm women related to dairy farming and home management in Ilam State of Iran. Livestock Res. Rural Develop., 19:201205.

Roberts, K. 2000. An analysis of group process in farmer learning: The Australian experience. J. Agric. Educ. Ext., 6:235244.

World Bank. 1999. India: Livestock Sector review: Enhancing growth and development. The World Bank and Allied Publishers: New Delhi.

\section{How to cite this article:}

Ram Niwas, Charu Sharma, Sunil Kumar Sharma and Chandra Prakash Meena. 2021. Management Practices and Perceived Training Needs of Livestock Farmers in Arid region of Rajasthan. Int.J.Curr.Microbiol.App.Sci. 10(07): 745-751. doi: https://doi.org/10.20546/ijcmas.2021.1007.081 